Pakula, R. (1951). J. gen. Microbiol. 5, 640-647.

\title{
Extraction of the T Antigen of Streptococcus pyogenes
}

\author{
By R. PAKULA* \\ Streptococcal Reference Laboratory, Public Health Laboratory Service, \\ Colindale, London, N.W.9
}

SUMMARY: The heat-stability of the T antigen of strains of Streptococcus pyogenes grown in Pope \& Smith (1932) broth (containing maltose and yeast) with added pancreatic extract varied considerably from strain to strain; with several strains 30 minutes' boiling was insufficient to eliminate all $T$ agglutinability.

By heating suspensions of streptococci to $80^{\circ}$ for $30 \mathrm{~min}$. and then treating the heated suspensions with trypsin-containing pancreatic extract for a few hours, $\mathbf{T}$ antigen was obtained in solution and could be demonstrated by precipitin tests with appropriate type-specific sera.

It is well known that streptococci of Lancefield's Group A (Streptococcus pyogenes) have two type-specific antigens, known as $\mathbf{M}$ and $\mathbf{T}$ (Lancefield, 1940-1). Both these antigens may be concerned in type identification by the slide agglutination method but the suspensions of streptococci that have to be used for this test are frequently unstable and the method commonly used for stabilizing them comprises digestion with trypsin-a process that destroys the $\mathbf{M}$ but not the $\mathbf{T}$ antigen. Consequently, in practical slide agglutination typing, one often has to rely on the $T$ antigen alone, which may be confusing owing to the sharing of $\mathbf{T}$ antigens by streptococci of different types (Stewart, Lancefield, Wilson \& Swift, 1944). For the precise study of the T antigen content of streptococci it would therefore be useful to be able to destroy this antigen in the cells without affecting the $\mathbf{M}$ antigen.

It would also be of great value if the $T$ antigen could be extracted from the cocci and demonstrated by a precipitin method similar to that used for the M antigen. Elliott (1943) and Lancefield \& Dole (1946) selectively destroyed the $\mathrm{T}$ antigen by heating the streptococcal suspension to $100^{\circ}$ for $30 \mathrm{~min}$.; and Lancefield \& Dole demonstrated that a $\mathbf{T}$-containing extract could be obtained by prolonged pepsin or trypsin digestion of the cocci. The present paper reports some extensions of this work.

\section{EXPERIMENTAL}

The antisera used were prepared at various times in this laboratory, usually by repeated intravenous inoculation of formalin-killed streptococci into rabbits, and were absorbed with heterologous strains to remove Group antibodies. The strains of streptococci used were all 'classical' strains, stored in the laboratory in the dried state. Agglutination tests were carried out by the slide technique, and precipitin tests by the method devised by Swift, Wilson \& Lancefield (1943) for M precipitin tests.

* World Health Organization Fellow, from State Institute of Hygiene, Warsaw. 


\section{Destruction of $\boldsymbol{T}$ antigen by heat}

It should be noted first that all the experiments reported here refer to loss of ability to agglutinate with $\mathrm{T}$ antisera, and that this is not necessarily the same as destruction of the $\mathbf{T}$ antigen. Testing for heat destruction of the $\mathbf{T}$ antigen by slide agglutination is often difficult because heated suspensions are very commonly unstable. It was found, however, that the digest broth described by Pope \& Smith (1943), to which had been added $1 \%(\mathrm{v} / \mathrm{v})$ pancreatic extract (containing about 50 standard units of trypsin/ml.), generally gave suspensions that were still satisfactory even after prolonged heating at $100^{\circ}$. Strains of Types $4,24,26,29$, and 46, which are known to share a common $\mathbf{T}$ antigen (Stewart et al., 1944) were grown in this medium

Table 1. Heat sensitivity of $\boldsymbol{T}$ antigen shown by slide agglutination tests

\begin{tabular}{|c|c|c|c|c|c|c|c|c|}
\hline & \multirow{2}{*}{$\begin{array}{c}\text { Time } \\
\text { of } \\
\text { boiling } \\
\text { (min.) }\end{array}$} & \multicolumn{7}{|c|}{ Serum $4(T)$ 'Wheatley' diluted } \\
\hline & & $1 / 20$ & $1 / 40$ & $\begin{array}{l}1 / 80 \\
\text { Agglv }\end{array}$ & $\begin{array}{l}1 / 160 \\
\text { tination }\end{array}$ & $\begin{array}{l}\text { 1/320 } \\
\text { esult }\end{array}$ & $1 / 640$ & $1 / 1280$ \\
\hline $\begin{array}{c}4 \\
\text { ‘T4' } \\
T\end{array}$ & $\begin{array}{c}\text { (min.) } \\
0 \\
5 \\
10 \\
20 \\
30 \\
40\end{array}$ & $\begin{array}{l}+++ \\
+++ \\
+++ \\
+++ \\
+++ \\
+++\end{array}$ & $\begin{array}{l}+++ \\
+++ \\
+++ \\
+++ \\
+++ \\
+++\end{array}$ & $\begin{array}{c}+++ \\
+++ \\
+++ \\
+++ \\
++ \\
++\end{array}$ & $\begin{array}{c}+++ \\
+++ \\
+++ \\
++ \\
++ \\
++\end{array}$ & $\begin{array}{c}+++ \\
+++ \\
+++ \\
+ \\
+ \\
-\end{array}$ & $\begin{array}{c}+++ \\
++ \\
++ \\
+ \\
- \\
-\end{array}$ & $\begin{array}{c}++ \\
++ \\
+ \\
- \\
- \\
-\end{array}$ \\
\hline $\begin{array}{c}24 \\
\text { 'C115' } \\
M \& T\end{array}$ & $\begin{array}{r}0 \\
5 \\
10 \\
20 \\
30 \\
40\end{array}$ & $\begin{array}{c}+++ \\
+++ \\
+++ \\
+ \\
+ \\
-\end{array}$ & $\begin{array}{c}+++ \\
+++ \\
+++ \\
+ \\
+ \\
-\end{array}$ & $\begin{array}{c}+++ \\
+++ \\
+++ \\
+ \\
+ \\
-\end{array}$ & $\begin{array}{c}+++ \\
+++ \\
++ \\
+ \\
- \\
-\end{array}$ & $\begin{array}{c}+++ \\
++ \\
++ \\
- \\
-\end{array}$ & $\begin{array}{c}++ \\
\pm \\
- \\
- \\
- \\
-\end{array}$ & $\begin{array}{l}++ \\
= \\
= \\
=\end{array}$ \\
\hline $\begin{array}{c}26 \\
\text { 'glossy' } \\
M \& T T\end{array}$ & $\begin{array}{r}0 \\
5 \\
10 \\
20 \\
\mathbf{3 0}\end{array}$ & $\begin{array}{c}+++ \\
++ \\
+ \\
+ \\
-\end{array}$ & $\begin{array}{c}+++ \\
++ \\
+ \\
+ \\
-\end{array}$ & $\begin{array}{c}+++ \\
++ \\
+ \\
+ \\
+\end{array}$ & $\begin{array}{c}+++ \\
++ \\
+ \\
\pm \\
-\end{array}$ & $\begin{array}{c}+++ \\
+ \\
- \\
-\end{array}$ & $\begin{array}{c}+++ \\
- \\
- \\
-\end{array}$ & $\begin{array}{c}++ \\
- \\
- \\
-\end{array}$ \\
\hline $\begin{array}{c}29 \\
\text { 'D23' } \\
M \& T\end{array}$ & $\begin{array}{l}0 \\
5\end{array}$ & ++ & ++ & $\frac{++}{-}$ & ++ & + & $\overline{-}$ & - \\
\hline $\begin{array}{c}46 \\
\text { 'C105' } \\
M \& T\end{array}$ & $\begin{array}{r}0 \\
5 \\
10 \\
20 \\
30 \\
40\end{array}$ & $\begin{array}{c}+++ \\
+++ \\
++ \\
++ \\
+ \\
+\end{array}$ & $\begin{array}{c}+++ \\
+++ \\
++ \\
++ \\
+ \\
+\end{array}$ & $\begin{array}{c}+++ \\
+++ \\
++ \\
++ \\
+ \\
+\end{array}$ & $\begin{array}{c}+++ \\
+++ \\
++ \\
+ \\
- \\
-\end{array}$ & $\begin{array}{c}++ \\
++ \\
+ \\
+ \\
- \\
-\end{array}$ & $\begin{array}{c}++ \\
+ \\
- \\
- \\
-\end{array}$ & $\begin{array}{l}++ \\
- \\
- \\
- \\
-\end{array}$ \\
\hline
\end{tabular}

Decreasing strength of agglutination is indicated by the symbols,,++++++ , and \pm , respectively; $-=$ no agglutination.

In this and all subsequent tables, the following conventions are adopted:

Numbers in bold type, e.g. $4=$ Type number.

Numbers in quotation e.g. ' $\mathbf{T} 4$ ' $=$ strain number or name.

Letters in italic, e.g. $M=$ antigen content of strain, or antibody content of serum. GMV 4 

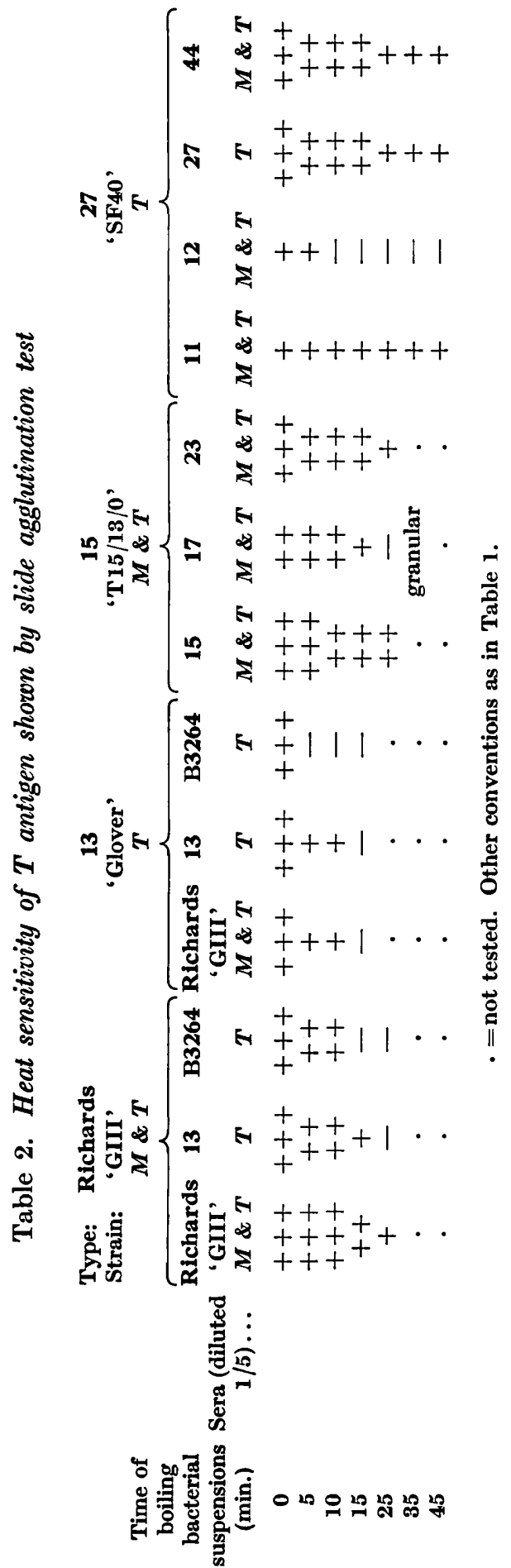
for 18-24 hr. at $37^{\circ}$; small samples of the cultures were boiled for varying times and then tested with dilutions of a Type 4 antiserum. Control tests were made with saline and with heterologous type-specific sera, and were in all cases negative. There was considerable variation in the duration of heating necessary to eliminate the T-agglutination (Table 1 ), and in three cases agglutination still occurred after $\mathbf{3 0} \mathrm{min}$. heating. Similar tests were carried out with other types, but in these cases the sera were used at one dilution only (1/5). The sera used included those of heterologous types thought to share a $\mathbf{T}$ antigen with the strain under test, because any agglutination thus observed would almost certainly be due to the shared $T$ antigen and could not be due to the heat-stable $M$ antigen. There was a similar variation in the time taken for loss of $\mathbf{T}$ agglutination (Table 2), perhaps partly to be explained by variations in the initial antibody titre of the serum, and in one case $30 \mathrm{~min}$. at $100^{\circ}$ was insufficient for complete destruction.

It seemed clear therefore that under our conditions, and with Pope \& Smith broth containing pancreatic extract, $30 \mathrm{~min}$. boiling could not, with all strains, be relied on to eliminate agglutination due to the $\mathbf{T}$ antigen. This differed from the published experience of other workers. The discrepancy is probably attributable to differences in culture media since in a number of experiments with strains of Types 4 and 8 grown in a meat-infusion nutrient broth enriched with $\mathbf{0 . 5} \%$ glucose, $5 \mathrm{~min}$. boiling usually proved sufficient to render the streptococci inagglutinable by $\mathbf{T}$ antisera. A typical result is shown in Table 3. This increased heat-lability was not, however, constant with different batches of broth and clearly requires much more investigation; it might be due to $\mathrm{pH}$ differences, since Lancefield \& Dole (1946) found a decreased $\mathrm{pH}$ to aid heat destruction of isolated $\mathrm{T}$ antigen, although in the present work the cocci were always washed well before testing.

Table 3. Loss of $T$ agglutinability on heating by streptococci grown in nutrient broth with $0.5 \%$ glucose

\begin{tabular}{|c|c|c|c|c|c|c|c|c|c|c|}
\hline \multirow[b]{2}{*}{ Strains } & \multirow[b]{2}{*}{$\begin{array}{c}\text { Sus- } \\
\text { pension }\end{array}$} & \multicolumn{8}{|c|}{ Serum $26, T$ only } & \multirow{2}{*}{$\begin{array}{l}\text { Serum } \\
\text { 26, } M \\
\text { (undil. }\end{array}$} \\
\hline & & $\begin{array}{c}\text { Un- } \\
\text { diluted }\end{array}$ & $1 / 20$ & $1 / 40$ & $1 / 80$ & $1 / 160$ & $\mathbf{1} / \mathbf{3 2 0}$ & $1 / 640$ & $1 / 1280$ & \\
\hline $\begin{array}{l}4 \\
T\end{array}$ & $\left\{\begin{array}{l}1 \\
2\end{array}\right.$ & $\begin{array}{c}++ \\
-\end{array}$ & $\begin{array}{c}++ \\
-\end{array}$ & $\begin{array}{c}++ \\
-\end{array}$ & $\begin{array}{c}++ \\
-\end{array}$ & $\begin{array}{c}++ \\
-\end{array}$ & $\begin{array}{c}++ \\
-\end{array}$ & $\begin{array}{c}++ \\
-\end{array}$ & $\overline{-}$ & - \\
\hline$\stackrel{26}{M \& T}$ & $\begin{array}{l}1 \\
2\end{array}$ & +++ & $\begin{array}{c}++ \\
-\end{array}$ & + & $\begin{array}{c}++ \\
-\end{array}$ & $\begin{array}{c}++ \\
-\end{array}$ & \pm & - & - & \\
\hline
\end{tabular}

Suspension 1-bacteria grown in Pope \& Smith broth, washed and boiled 5 min.

Suspension 2-bacteria grown in nutrient broth with $0.5 \%$ glucose, washed and boiled 5 min.

Other conventions as in Table 1.

It was then found that specific $T$ agglutination of cocci grown in Pope \& Smith broth was lost after only a short period of heating when the cocci were first treated with pancreatic extract for about 1.5 hr. The loss of the $\mathrm{T}$ agglutination could also be achieved by treatment with pancreatic extract 
for $1.5 \mathrm{hr}$. subsequent to $10 \mathrm{~min}$. boiling (Table 4). Lancefield \& Dole showed, and $I$ have confirmed, that such treatment itself produces no demonstrable effect on specific agglutination by $\mathrm{T}$ antisera.

Table 4. Loss of $T$ agglutinability after boiling and trypsin digestion

\begin{tabular}{|c|c|c|c|}
\hline \multicolumn{4}{|c|}{ Sera } \\
\hline $\begin{array}{c}4 \\
\text { 'Wheatley' } \\
T\end{array}$ & $\begin{array}{c}24 \\
\text { 'G54' } \\
T \\
\text { Agglutin }\end{array}$ & $\begin{array}{c}26 \\
\text { 'Glossy' } \\
T \\
\text { result }\end{array}$ & $\begin{array}{c}46 \\
{ }^{\circ} 105 \\
M \& T\end{array}$ \\
\hline
\end{tabular}

\begin{tabular}{|c|c|c|c|c|c|}
\hline & & & & & \\
\hline 4, 'T $\mathbf{T}$ 4' & 1 & +++ & $++t$ & +++ & +++ \\
\hline $\begin{array}{c}24, ' C 115 \text { ' } \\
\quad M \& T\end{array}$ & $\begin{array}{l}1 \\
\mathbf{2}\end{array}$ & $\begin{array}{c}++ \\
-\end{array}$ & $\begin{array}{c}++ \\
-\end{array}$ & $\begin{array}{c}++ \\
-\end{array}$ & $\begin{array}{c}++ \\
-\end{array}$ \\
\hline $\begin{array}{l}\text { 26, 'Glossy' } \\
\text { M \& T }\end{array}$ & $\begin{array}{l}\mathbf{1} \\
\mathbf{2}\end{array}$ & ++ & $+t+$ & $\begin{array}{c}++ \\
-\end{array}$ & ++ \\
\hline $\begin{array}{l}28, \text { 'D 140A' } \\
M \& T\end{array}$ & $\begin{array}{l}\mathbf{1} \\
\mathbf{2}\end{array}$ & $\begin{array}{c}+++ \\
++\end{array}$ & + & + & + \\
\hline $\begin{array}{c}\text { 29, 'D23' } \\
\text { M \& T }\end{array}$ & $\begin{array}{l}\mathbf{1} \\
\mathbf{2}\end{array}$ & \pm & - & - & \pm \\
\hline $\begin{array}{c}\text { 46, 'C } 105 \text { ' } \\
\text { M \& T }\end{array}$ & $\begin{array}{l}1 \\
2\end{array}$ & $+t+$ & ++ & ++ & ++ \\
\hline
\end{tabular}

Suspension 1 boiled for $10 \mathrm{~min}$.

Suspension 2 boiled for $10 \mathrm{~min}$. and subsequently treated with pancreatic extract for $1.5 \mathrm{hr}$.

Other conventions as in Table 1.

After treatment by boiling and pancreatic extract all the cross-reactions between strains and sera of Types 4, 24, 26, 28, 29 and 46 which were attributable to the common $\mathrm{T}$ antigen were lost. There remained a cross-reaction between Types 4 and 28; but it will be remembered that the $M$ antigen of Type 28, unlike those of other types, is not trypsin-sensitive and it is just possible that this cross-reaction resulted from the presence in the Type 4 serum of some antibody to this antigen of Type 28. Rarely, when the strains were treated with pancreatic extract before boiling, they showed minor crossreactions; but more often all agglutinability was lost as when the treatment was carried out after boiling.

\section{Extraction of $\boldsymbol{T}$ antigen}

Lancefield \& Dole (1946) obtained enough $\mathbf{T}$ antigen for precipitin tests in the supernatant fluids of 'trypsinized' suspensions with only one type, namely, Type 1 ; for other types the extracts had to be concentrated from much larger quantities of culture. In their hands the $T$ antigen appeared to be rapidly destroyed by heating. The ease with which, in our experiments, heated cocci lost their $\mathbf{T}$ antigen when treated with pancreatic extract suggested that the antigen might be liberated into the supernatant fluid rather than destroyed 
by this combination of treatments. Cultures of strains of Types 4, 24, 26, and 46 grown in 1 litre volumes of buffered glucose broth (modified from Todd \& Hewitt, 1932) at $37^{\circ}$ overnight, were centrifuged, washed several times and resuspended in $2.7 \mathrm{ml}$. saline; the suspension was boiled for $5 \mathrm{~min}$. and cooled; $0.3 \mathrm{ml}$. of pancreatic extract was then added and the $\mathrm{pH}$ brought to $\mathbf{8 \cdot 2}$. After $4 \mathrm{hr}$. digestion at $37^{\circ}$ the supernatant fluids from the centrifuged suspensions were tested for precipitinogen with sera of Types 4 and 46 known to contain $\mathbf{T}$ antibodies for all the strains tested. However, only the extracts from the Type 4 and 46 strains gave precipitates with the Type 4 antiserum and none precipitated with the Type 46 serum. Following the method of Lancefield \& Dole the extracts were brought to $\mathrm{pH} 2.5$; the resulting precipitates were separated and dissolved in $0.5 \mathrm{ml}$. of $\mathrm{pH} 7.8$ phosphate buffer. The Type 4 and 46 extracts concentrated in this way both gave precipitates with Type 4 and 46 antisera, but Types 24 and 26 still gave no precipitates. Extracts containing $\mathbf{T}$ antigens reacting with homologous sera were, however, prepared by this method from strains of Types 1, 2, and 25, but not from strains of Types 12 and 22.

Table 5. Loss of $T$ agglutinability by heating and treatment with pancreatic extract

\begin{tabular}{|c|c|c|c|c|c|c|c|c|}
\hline & & & & Seru & dilutio & & & \\
\hline & & $1 / 20$ & $1 / 40$ & $1 / 80$ & $1 / 160$ & $1 / 320$ & $1 / 640$ & $1 / 1280$ \\
\hline Strains & Suspension & & & & & & & \\
\hline $\begin{array}{l}4 \\
\text { 'T4 } \\
T\end{array}$ & $\left\{\begin{array}{l}1 \\
2 \\
3\end{array}\right.$ & $\begin{array}{c}+++ \\
+++ \\
+\end{array}$ & $\begin{array}{c}+++ \\
+++ \\
+\end{array}$ & $\begin{array}{c}++t \\
+++ \\
+\end{array}$ & $\begin{array}{c}+++ \\
++ \\
+\end{array}$ & $\begin{array}{c}+++ \\
++ \\
+\end{array}$ & $\begin{array}{c}+++ \\
++ \\
+\end{array}$ & $\begin{array}{c}++ \\
+ \\
-\end{array}$ \\
\hline 27 & 1 & $+t+$ & +++ & $+t+$ & $++t$ & ++ & + & - \\
\hline ‘SF40' & $\{2$ & $++t$ & $+t+$ & $+t+$ & +++ & $+t$ & - & - \\
\hline$T$ & $\dot{3}$ & ++ & ++ & ++ & + & + & - & - \\
\hline 46 & & +++ & +++ & +++ & +++ & +++ & ++ & + \\
\hline $\begin{array}{l}' \mathrm{C} 105 ' \\
M \& T\end{array}$ & $\left\{\begin{array}{l}2 \\
3\end{array}\right.$ & $\begin{array}{c}++ \\
+\end{array}$ & $\begin{array}{c}++ \\
+\end{array}$ & $\begin{array}{c}++ \\
+\end{array}$ & $\begin{array}{c}++ \\
+\end{array}$ & + & + & - \\
\hline & & & † & + & \pm & - & - & - \\
\hline
\end{tabular}

Suspensions: 1-untreated.

2 -heated $10 \mathrm{~min}$. at $80^{\circ}$.

3 -heated $10 \mathrm{~min}$. at $80^{\circ}$ and treated with pancreatic extract for $1.5 \mathrm{hr}$.

* The sera used were of homologous $T$ type for the suspensions, namely, for 4 , a 'Wheatley' $(T)$ serum; for 27 a 'T27' $(T)$ serum; and for 46, a 'T46' $(T)$ serum.

Other conventions as in Table 1.

It seemed that, in some strains, heating to $100^{\circ}$ decreased the $\mathrm{T}$ antigen content of the cells to an extent that they no longer yielded active extracts. It was then found that heating to $80^{\circ}$ for $10 \mathrm{~min}$. or to $60^{\circ}$ for $30-60 \mathrm{~min}$. was sufficient to increase the speed at which pancreatic extract caused loss of $T$ agglutination without destroying the antigen (Table 5). Extracts from $18 \mathrm{hr}$. cultures grown at $37^{\circ}$ in $500 \mathrm{ml}$. volumes of Todd \& Hewitt broth, Pope \& Smith broth, or nutrient broth with glucose, and heated in this way, gave specific precipitation with the homologous $T$ antisera, when strains containing 
$\mathrm{T}$ antigen and sera with a titre of $\mathrm{T}$ antibodies of $1 / 320$ or more, as determined by slide agglutination, were used. The following Types were tested: 1, 2, 4, 8, 9, 12, 13, 22, 24, 25, 26, 27, 29, 44, and provisional Types Richards, B3264, Impetigo 19. For Types 24 and 26, 1.5 l. volumes of culture were necessary and for Type 24 it was necessary to grow at $22^{\circ}$ rather than at $37^{\circ}$. Elliott (1943) showed that growth at $22^{\circ}$ enhanced the production of $\mathrm{T}$ antigen of Type 28. Types 1, 2, 8, 25, 44, and Impetigo 19 yielded satisfactory extracts from $250 \mathrm{ml}$. cultures.

The amount of $\mathrm{T}$ antigen in the extract was not affected by heating for $30 \mathrm{~min}$. at $56^{\circ}$, nor by $10 \mathrm{~min}$. at $80^{\circ}$; it was greatly decreased after $10 \mathrm{~min}$. at $100^{\circ}$ at $\mathrm{pH} 7-8$, and often almost completely inactivated.

\section{Demonstration of cross-reactions due to $T$ antigen by slide agglutination and precipitin tests}

The cross-reactions due to shared $T$ antigens among a set of strains of Types 4, 24, 26, 28, 29, and 46, were first demonstrated by Stewart et al. (1944) by agglutination, and by Lancefield \& Dole (1946) by precipitation. I was able to confirm these results when the same strains were tested by the slide agglutination method (Table 6), except that no T-containing antisera were available for Types 28 and 29. The same cross-reactions were observed by precipitin tests with extracts prepared by heat and treatment with pancreatic extract as described above.

In order to demonstrate the similarity of the extracts prepared by heat and pancreatic extract treatment to those studied by Lancefield \& Dole, attempts were made to demonstrate parallel cross-reactions by slide agglutination and T precipitin tests with other groups of strains which are suspected, from experience of slide agglutination typing, to have common $\mathrm{T}$ antigens. The results from three such groups are shown in Tables 7-9. It is clear that in the 12/27/44 (Table 7) and 8/25/Imp.19 (Table 8) sets, the $\mathrm{T}$ extracts gave precipitates with those sera agglutinating the streptococcal suspensions to titres of around $1 / 160$ or more, and in the $8 / 25 / \mathrm{Imp} .19$ set, the cross-reactions, having titres lower than this, were not shown by the precipitin method. The results in the Richards/13/B3264 (Table 9) set, although not so clear, were substantially the same.

\section{DISCUSSION}

It seems clear from the present work that the ease with which the $\mathbf{T}$ antigen can be destroyed by heat depends partly on the strain (as shown for example by the difference between the strains of Types 4 and 29; Table 1) and partly on the medium in which the cocci are grown. This point clearly needs much further investigation since it is of importance both in practice for obtaining the best absorbing suspensions for making single-antibody sera, and for the theoretical information that it may give about the surface structure of the streptococci. That the 'destruction' of the T antibody is more complex than at first appears is further shown by the additive effects of heat and treatment 


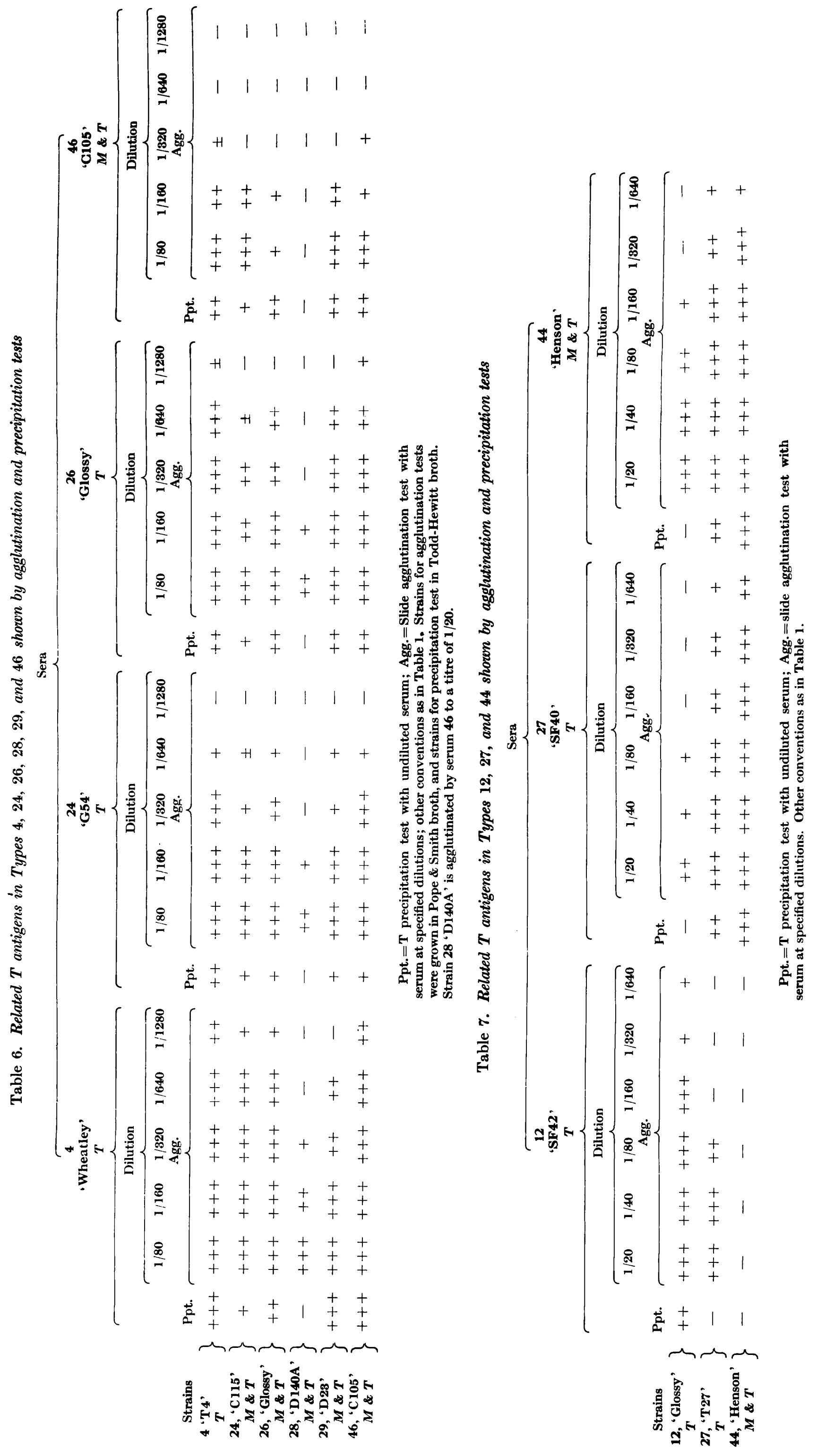



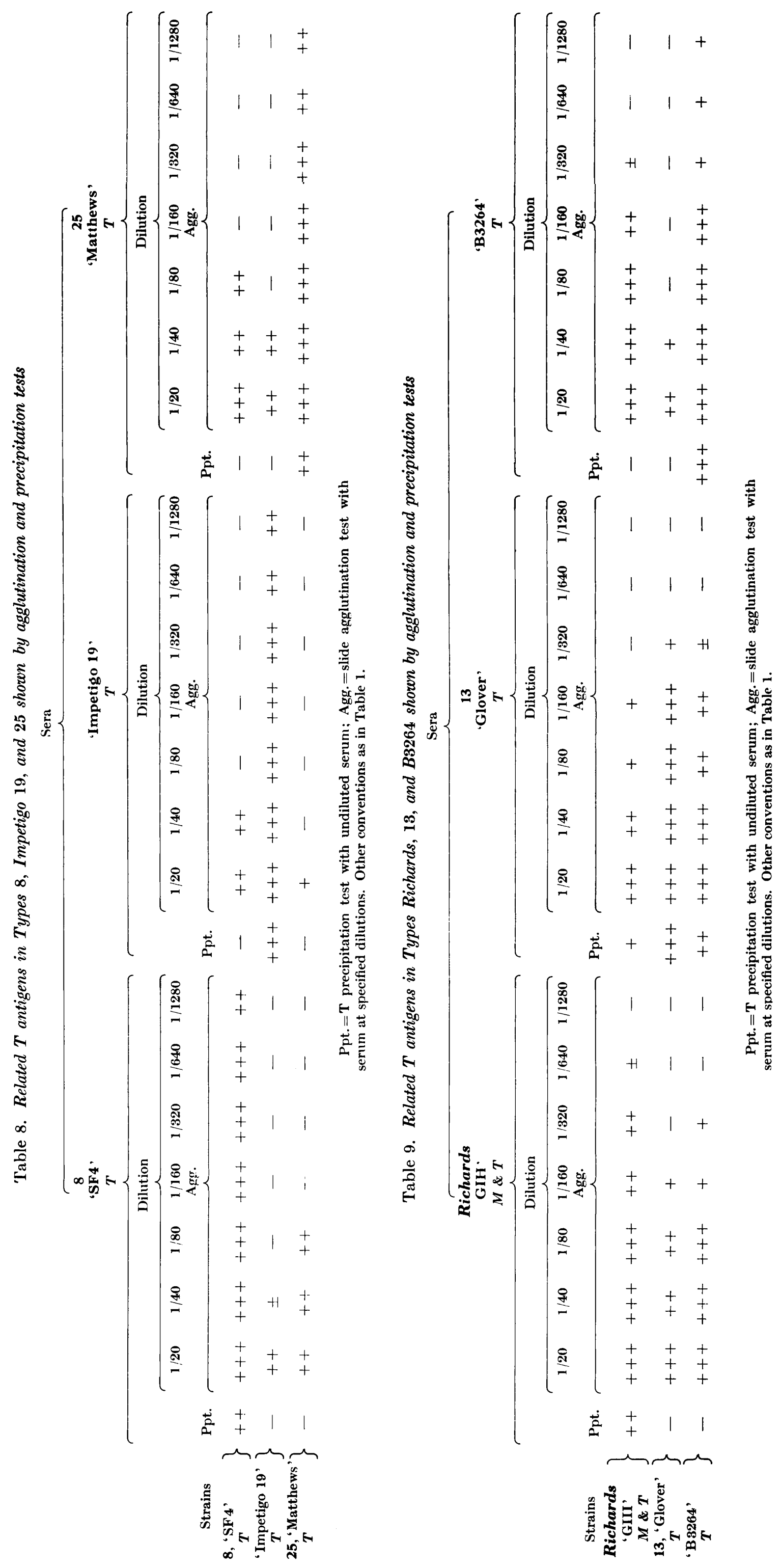
with pancreatic extract. Furthermore it has been found that antisera prepared in this laboratory, by using as antigen autoclaved (one case) or boiled vaccines, can induce the formation of $\mathbf{T}$ antibodies in rabbits.

The preliminary heating of the streptococci before treatment with pancreatic extract appears to offer a useful method for increasing the yield of soluble $\mathrm{T}$ antigen, and with most of the limited number of strains tested the unconcentrated supernatant fluid from digestion (in 1.5-2.5 ml.) of the cocci from $500 \mathrm{ml}$. broth has given satisfactory precipitates with sera of adequate titre. Such extracts show cross-reactions between different sera of the same pattern as are found in slide agglutination tests and thus behave in the same way as the extracts obtained by Lancefield \& Dole (1946).

\section{REFERENCES}

Elliotr, S. D. (1943). Type relationships amongst Group A streptococci. Brit. J. exp. Path. 24, 159.

LANCEField, ReBecca C. (1940-1). Specific relationship of cell composition to biological activity of the haemolytic streptococci. Harvey Lect. 36, 251.

Lancefield, Rebecca C. \& Dole, V. P. (1946). The properties of T antigens extracted from Group A streptococci. J. exp. Med. 84, 449.

Pope, C. G. \& Smith, Margaret L. (1932). The routine preparation of diphtheria toxin of high value. J. Path. Bact. 35, 573.

Stewart, W. A., Lancefield, Rebecca C., Wilson, A. T. \& Swift, H. F. (1944). Studies on the antigenic composition of Group A haemolytic streptococci. IV. Related $T$ but distinct $M$ antigens in Types 15, 17, 19, 23, 30 and in Types 4, 24, 26, 28, 29, 46. Identification by slide agglutination. J. exp. Med. 79, 99.

Swift, H. F., Wilson, A. T. \& Lancefield, Rebecca C. (1943). Typing Group A haemolytic streptococci by $M$ precipitin reactions in capillary pipettes. $J$. exp. Med. 78, 127.

TodD, E. W. \& Hewirt, L. F. (1932). A new culture medium for the production of antigenic streptococcal haemolysin. J. Path. Bact. 35, 973.

(Received 27 July 1950) 